\title{
ÍNDICE Do Volume 92 RBEP
}

Este índice refere-se às matérias do volume 92 (números 230, 231 e 232) da Revista Brasileira de Estudos Pedagógicos. Divide-se em três partes, de acordo com os diferentes pontos de acesso: Assuntos, Autores e Títulos.

Quanto ao Índice de Assuntos:

- os termos usados para indexação são extraídos do Thesaurus Brasileiro de Educação (Brased);

- cada palavra dos termos compostos abre uma entrada, por exemplo:

Avaliação do ensino superior ensino superior, Avaliação do

superior, Avaliação do ensino

Quanto ao Índice de Autores:

- arrolados pelo último sobrenome;

- um traço é usado para substituir o nome quando há mais de uma entrada para o mesmo autor.

Quanto ao Índice de Títulos:

- os artigos que iniciam o título não são considerados. 



\section{ÍNDICE DE ASSUNTOS RBEP}

\section{Ação política}

SOUSA, Letícia Pereira; PORTES, Écio Antônio. As propostas de políticas/ ações afirmativas das universidades públicas e as políticas/ações de permanência nos ordenamentos legais. RBEP, v. 92, n. 232, p. 516-541, set./dez. 2011. Seção: Estudos.

\section{Acesso ao ensino}

SOUSA, Letícia Pereira; PORTES, Écio Antônio. As propostas de políticas/ ações afirmativas das universidades públicas e as políticas/ações de permanência nos ordenamentos legais. RBEP, v. 92, n. 232, p. 516-541, set./dez. 2011. Seção: Estudos.

\section{Ações afirmativas}

AGOSTINHO, Luis Otávio Vincenzi; BREGA FILHO, Vladimir. Por um olhar democrático às ações afirmativas. RBEP, v. 92, n. 232, p. 455-476, set./ dez. 2011. Seção: Estudos.

DOEBBER, Michele Barcelos; GRISA, Gregório Durlo. Ações afirmativas: o critério racial e a experiência da Universidade Federal do Rio Grande do Sul. RBEP, v. 92, n. 232, p. 577-598, set./dez. 2011. Seção: Estudos.

PEREIRA, Sueli Menezes; ZIENTARSKI, Clarice. Políticas de ações afirmativas e pobreza no Brasil. RBEP, v. 92, n. 232, p. 493-515, set./dez. 2011. Seção: Estudos. 
VELLOSO, Jacques; CARDOSO, Claudete Batista. Um quinquênio de cotas: as chances de ingresso de negros na Universidade de Brasília. RBEP, v. 92, n. 231, p. 221-245, maio/ago. 2011. Seção: Estudos.

\section{Acompanhamento}

MARTINS, Regina Maria Caruccio. Discussão em torno da noção de acompanhamento de jovens adultos na educação superior. RBEP, v. 92, n. 231, p. 417-433, maio/ago. 2011. Seção: Estudos.

\section{adolescentes, Alunos}

BUENO, Fabrício Aparecido; SANT'ANA, Ruth Bernardes de. A experiência geracional na fala de alunos de escola pública: a questão da autoridade docente. RBEP, v. 92, n. 231, p. 316-340, maio/ago. 2011. Seção: Estudos.

\section{adultos, Formação de}

MARTINS, Regina Maria Caruccio. Discussão em torno da noção de acompanhamento de jovens adultos na educação superior. RBEP, v. 92, n. 231, p. 417-433, maio/ago. 2011. Seção: Estudos.

\section{afirmativas, Ações}

AGOSTINHO, Luis Otávio Vincenzi; BREGA FILHO, Vladimir. Por um olhar democrático às ações afirmativas. RBEP, v. 92, n. 232, p. 455-476, set./ dez. 2011. Seção: Estudos.

DOEBBER, Michele Barcelos; GRISA, Gregório Durlo. Ações afirmativas: o critério racial e a experiência da Universidade Federal do Rio Grande do Sul. RBEP, v. 92, n. 232, p. 577-598, set./dez. 2011. Seção: Estudos.

PEREIRA, Sueli Menezes; ZIENTARSKI, Clarice. Políticas de ações afirmativas e pobreza no Brasil. RBEP, v. 92, n. 232, p. 493-515, set./dez. 2011. Seção: Estudos.

VELLOSO, Jacques; CARDOSO, Claudete Batista. Um quinquênio de cotas: as chances de ingresso de negros na Universidade de Brasília. RBEP, v. 92, n. 231, p. 221-245, maio/ago. 2011. Seção: Estudos.

\section{agrária, Reforma}

MARQUES, Waldemar; FRANCO, Fernando Silveira; SCHLINDWEIN, Marcelo Nivert. Universidade e movimentos sociais no Brasil: uma experiência de ação afirmativa. RBEP, v. 92, n. 232, p. 557-576, set./dez. 2011. Seção: Estudos.

\section{Agroecologia}

MARQUES, Waldemar; FRANCO, Fernando Silveira; SCHLINDWEIN, Marcelo Nivert. Universidade e movimentos sociais no Brasil: uma experiência de ação afirmativa. RBEP, v. 92, n. 232, p. 557-576, set./dez. 2011. Seção: Estudos. 


\section{Alfabetização}

CRUZ, Magna Silva; ALBUQUERQUE, Eliana Borges. Alfabetização e letramento no $1^{\circ}$ ciclo: o que as crianças aprendem sobre a escrita a cada ano? RBEP, v. 92, n. 230, p. 126-147, jan./abr. 2011. Seção: Estudos.

SIQUEIRA, Idméa Semeghini. Recursos educacionais apropriados para recuperação lúdica do processo de letramento emergente. RBEP, v. 92, n. 230, p. 148-165, jan./abr. 2011. Seção: Estudos.

\section{Alunos adolescentes}

BUENO, Fabrício Aparecido; SANT'ANA, Ruth Bernardes de. A experiência geracional na fala de alunos de escola pública: a questão da autoridade docente. RBEP, v. 92, n. 231, p. 316-340, maio/ago. 2011. Seção: Estudos.

\section{ambiental, Educação}

OSÓRIO, Mara Rejane Vieira. Professores e Educação Ambiental: implicações para o currículo. RBEP, v. 92, n. 231, p. 399-416, maio/ago. 2011. Seção: Estudos.

\section{Análise multivariada}

FACCENDA, Odival; DALBEN, Adilson; FREITAS, Luiz Carlos de. Capacidade explicativa de questionários de contexto: aspectos metodológicos. RBEP, v. 92, n. 231, p. 246-267, maio/ago. 2011. Seção: Estudos.

\section{Aprendizagem}

BRUNO, Lúcia. Gestão da educação escolar indígena diferenciada: contradições, limites e possibilidades. RBEP, v. 92, n. 232, p. 639-662, set./dez. 2011. Seção: Estudos.

CRUZ, Magna Silva; ALBUQUERQUE, Eliana Borges. Alfabetização e letramento no $1^{\circ}$ ciclo: o que as crianças aprendem sobre a escrita a cada ano? RBEP, v. 92, n. 230, p. 126-147, jan./abr. 2011. Seção: Estudos.

\section{Apropriação}

CESTARI, Luiz Artur Santos. Autobiografias e formação: aproximações problemáticas no Movimento Pesquisa/Formação. RBEP, v. 92, n. 230, p. 83-106, jan./abr. 2011. Seção: Estudos.

\section{Argentina}

PEREIRA, Marcos Villela; FARE, Mónica de La. A formação de professores para Educação de Jovens e Adultos (EJA): as pesquisas na Argentina e no Brasil. RBEP, v. 92, n. 230, p. 70-82, jan./abr. 2011. Seção: Estudos.

\section{Atribuições específicas dos entes federados}

GOMES, Magno Federeci. Delimitação de atribuições educacionais: sistemas de ensino e competência constitucional. RBEP, v. 92, n. 230, p. 166-186, jan./abr. 2011. Seção: Estudos. 


\section{Autobiografias}

CESTARI, Luiz Artur Santos. Autobiografias e formação: aproximações problemáticas no Movimento Pesquisa/Formação. RBEP, v. 92, n. 230, p. 83-106, jan./abr. 2011. Seção: Estudos.

\section{Autoridade docente}

AZEVEDO, Fernanda Vicente de; BOMBASSARO, Ticiane; VAZ, Alexandre Fernandez. Escolarização do corpo e controle de si na revista Estudos Educacionais. RBEP, v. 92, n. 231, p. 302-315, maio/ago. 2011. Seção: Estudos.

BUENO, Fabrício Aparecido; SANT'ANA, Ruth Bernardes de. A experiência geracional na fala de alunos de escola pública: a questão da autoridade docente. RBEP, v. 92, n. 231, p. 316-340, maio/ago. 2011. Seção: Estudos.

\section{Avaliação}

VOLPATO, Gildo. A universidade na sua constituição: criação, reformas e implicações político-epistemológicas. RBEP, v. 92, n. 232, p. 678-701, set./dez. 2011. Seção: Estudos.

\section{básica, Escola}

PEREIRA, Sueli Menezes; ZIENTARSKI, Clarice. Políticas de ações afirmativas e pobreza no Brasil. RBEP, v. 92, n. 232, p. 493-515, set./dez. 2011. Seção: Estudos.

\section{Brasil}

PEREIRA, Marcos Villela; FARE, Mónica de La. A formação de professores para Educação de Jovens e Adultos (EJA): as pesquisas na Argentina e no Brasil. RBEP, v. 92, n. 230, p. 70-82, jan./abr. 2011. Seção: Estudos.

\section{campo, Educação no}

MARQUES, Waldemar; FRANCO, Fernando Silveira; SCHLINDWEIN, Marcelo Nivert. Universidade e movimentos sociais no Brasil: uma experiência de ação afirmativa. RBEP, v. 92, n. 232, p. 557-576, set./dez. 2011. Seção: Estudos.

\section{Cenários sociais pós-coloniais}

BARBOSA, Manuel Gonçalves. Educação e imaginário intercultural: recomposição do papel da sociedade civil. RBEP, v. 92, n. 232, p. 477-492, set./dez. 2011. Seção: Estudos.

\section{Chances de ingresso}

VELLOSO, Jacques; CARDOSO, Claudete Batista. Um quinquênio de cotas: as chances de ingresso de negros na Universidade de Brasília. RBEP, v. 92, n. 231, p. 221-245, maio/ago. 2011. Seção: Estudos. 


\section{ciclos, Sistema de}

CRUZ, Magna Silva; ALBUQUERQUE, Eliana Borges. Alfabetização e letramento no $1^{\circ}$ ciclo: o que as crianças aprendem sobre a escrita a cada ano? RBEP, v. 92, n. 230, p. 126-147, jan./abr. 2011. Seção: Estudos.

\section{coloniais, Cenários sociais pós-}

BARBOSA, Manuel Gonçalves. Educação e imaginário intercultural: recomposição do papel da sociedade civil. RBEP, v. 92, n. 232, p. 477-492, set./dez. 2011. Seção: Estudos.

\section{Competência em matéria educacional}

GOMES, Magno Federeci. Delimitação de atribuições educacionais: sistemas de ensino e competência constitucional. RBEP, v. 92, n. 230, p. 166-186, jan./abr. 2011. Seção: Estudos.

\section{Concepções}

SILVA, Sérgio Pereira da. Pedagogia do Ressentimento: o otimismo nas concepções e nas práticas de ensino. RBEP, v. 92, n. 230, p. 107-125, jan./ abr. 2011. Seção: Estudos.

\section{Condição de estudante}

ÁVILA, Rebeca Contrera. Estudantes de camadas populares e o ingresso na vida universitária. RBEP, v. 92, n. 232, p. 757-764, set./dez. 2011. Seção: Resenhas.

\section{Condições socioeducacionais}

SOUSA, Letícia Pereira; PORTES, Écio Antônio. As propostas de políticas/ ações afirmativas das universidades públicas e as políticas/ações de permanência nos ordenamentos legais. RBEP, v. 92, n. 232, p. 516-541, set./dez. 2011. Seção: Estudos.

\section{Conhecimento}

BRUNO, Lúcia. Gestão da educação escolar indígena diferenciada: contradições, limites e possibilidades. RBEP, v. 92, n. 232, p. 639-662, set./dez. 2011. Seção: Estudos.

\section{Construção e interpretação de gráficos e tabelas}

PAGAN, Adriana; MAGINA, Sandra. O ensino de Estatística na educação básica com foco na interdisciplinaridade: um estudo comparativo. RBEP, v. 92, n. 232, p. 723-738, set./dez. 2011. Seção: Estudos.

\section{conteúdo-método, Relação}

NEITZEL, Adair Aguiar; FERRI, Cássia. Formação continuada para professores da educação básica: metodologia do currículo integrado e laboratório de vivências pedagógicas. RBEP, v. 92, n. 230, p. 52-69, jan./ abr. 2011. Seção: Estudos. 


\section{continuada, Formação}

LEAL, Telma Ferraz; FERREIRA, Andrea Tereza Brito. Formação continuada e ensino da escrita: análise de estratégias formativas utilizadas no programa Pró-Letramento. RBEP, v. 92, n. 231, p. 370-385, maio/ago. 2011. Seção: Estudos.

\section{Contrato didático}

ARAUJO, Lucia de Fátima; LIMA, Anna Paula de Avelar Brito; SANTOS, Marcelo Câmara dos. Ruptura e efeitos do contrato didático numa aula de resolução de problemas algébricos. RBEP, v. 92, n. 232, p. 739-756, set./dez. 2011. Seção: Estudos.

\section{contrato, Efeitos de}

ARAUJO, Lucia de Fátima; LIMA, Anna Paula de Avelar Brito; SANTOS, Marcelo Câmara dos. Ruptura e efeitos do contrato didático numa aula de resolução de problemas algébricos. RBEP, v. 92, n. 232, p. 739-756, set./dez. 2011. Seção: Estudos.

\section{Corpo}

AZEVEDO, Fernanda Vicente de; BOMBASSARO, Ticiane; VAZ, Alexandre Fernandez. Escolarização do corpo e controle de si na revista Estudos Educacionais. RBEP, v. 92, n. 231, p. 302-315, maio/ago. 2011. Seção: Estudos.

\section{cotas, Sistema de}

VELLOSO, Jacques; CARDOSO, Claudete Batista. Um quinquênio de cotas: as chances de ingresso de negros na Universidade de Brasília. RBEP, v. 92, n. 231, p. 221-245, maio/ago. 2011. Seção: Estudos.

\section{Cotidiano escolar}

SIQUEIRA, Flávia Zanni. Psicanálise aplicada ao estudo do cotidiano escolar. RBEP, v. 92, n. 230, p. 187-199, jan./abr. 2011. Seção: Estudos.

\section{Criação}

MOURA, Eliana P. G. de; ZUCCHETTI, Dinora Tereza; MENEZES, Magali Mendes de. Cultura e resistência: a criação do popular e o popular como criação. RBEP, v. 92, n. 232, p. 663-677, set./dez. 2011. Seção: Estudos.

\section{Crise}

PEREIRA, Júlio Emílio Diniz. O ovo ou a galinha: a crise da profissão docente e a aparente falta de perspectiva para a educação brasileira. RBEP, v. 92, n. 230, p. 34-51, jan./abr. 2011. Seção: Estudos.

\section{Cultura popular}

MOURA, Eliana P. G. de; ZUCCHETTI, Dinora Tereza; MENEZES, Magali Mendes de. Cultura e resistência: a criação do popular e o popular como criação. RBEP, v. 92, n. 232, p. 663-677, set./dez. 2011. Seção: Estudos. 


\section{cultura universitária, Inclusão e}

BRUNO, Marilda Moraes Garcia. Políticas afirmativas para a inclusão do surdo no ensino superior: algumas reflexões sobre o acesso, a permanência e a cultura universitária. RBEP, v. 92, n. 232, p. 542-556, set./dez. 2011. Seção: Estudos.

\section{cultural, Diversificação}

BARBOSA, Manuel Gonçalves. Educação e imaginário intercultural: recomposição do papel da sociedade civil. RBEP, v. 92, n. 232, p. 477-492, set./dez. 2011. Seção: Estudos.

\section{Curso de pedagogia}

NEITZEL, Adair Aguiar; FERRI, Cássia. Formação continuada para professores da educação básica: metodologia do currículo integrado e laboratório de vivências pedagógicas. RBEP, v. 92, n. 230, p. 52-69, jan./ abr. 2011. Seção: Estudos.

\section{Desigualdades educacionais}

ROSISTOLATO, Rodrigo Pereira da Rocha. Juventudes populares em um pré-vestibular: a construção coletiva de expectativas e campos de possibilidades educacionais. RBEP, v. 92, n. 232, p. 616-638, set./dez. 2011. Seção: Estudos.

\section{Didática}

NEITZEL, Adair Aguiar; FERRI, Cássia. Formação continuada para professores da educação básica: metodologia do currículo integrado e laboratório de vivências pedagógicas. RBEP, v. 92, n. 230, p. 52-69, jan./ abr. 2011. Seção: Estudos.

\section{didático, Contrato}

ARAUJO, Lucia de Fátima; LIMA, Anna Paula de Avelar Brito; SANTOS, Marcelo Câmara dos. Ruptura e efeitos do contrato didático numa aula de resolução de problemas algébricos. RBEP, v. 92, n. 232, p. 739-756, set./dez. 2011. Seção: Estudos.

\section{didáticos, Recursos}

SIQUEIRA, Idméa Semeghini. Recursos educacionais apropriados para recuperação lúdica do processo de letramento emergente. RBEP, v. 92, n. 230, p. 148-165, jan./abr. 2011. Seção: Estudos.

\section{Direito educacional}

GOMES, Magno Federeci. Delimitação de atribuições educacionais: sistemas de ensino e competência constitucional. RBEP, v. 92, n. 230, p. 166-186, jan./abr. 2011. Seção: Estudos.

\section{Discursos}

OSÓRIO, Mara Rejane Vieira. Professores e Educação Ambiental: 
implicações para o currículo. RBEP, v. 92, n. 231, p. 399-416, maio/ago. 2011. Seção: Estudos.

\section{Diversificação cultural}

BARBOSA, Manuel Gonçalves. Educação e imaginário intercultural: recomposição do papel da sociedade civil. RBEP, v. 92, n. 232, p. 477-492, set./dez. 2011. Seção: Estudos.

\section{docente, Autoridade}

AZEVEDO, Fernanda Vicente de; BOMBASSARO, Ticiane; VAZ, Alexandre Fernandez. Escolarização do corpo e controle de si na revista Estudos Educacionais. RBEP, v. 92, n. 231, p. 302-315, maio/ago. 2011. Seção: Estudos.

BUENO, Fabrício Aparecido; SANT'ANA, Ruth Bernardes de. A experiência geracional na fala de alunos de escola pública: a questão da autoridade docente. RBEP, v. 92, n. 231, p. 316-340, maio/ago. 2011. Seção: Estudos.

\section{Educação}

BARBOSA, Manuel Gonçalves. Educação e imaginário intercultural: recomposição do papel da sociedade civil. RBEP, v. 92, n. 232, p. 477-492, set./dez. 2011. Seção: Estudos.

ROSISTOLATO, Rodrigo Pereira da Rocha. Juventudes populares em um pré-vestibular: a construção coletiva de expectativas e campos de possibilidades educacionais. RBEP, v. 92, n. 232, p. 616-638, set./dez. 2011. Seção: Estudos.

\section{Educação ambiental}

OSÓRIO, Mara Rejane Vieira. Professores e Educação Ambiental: implicações para o currículo. RBEP, v. 92, n. 231, p. 399-416, maio/ago. 2011. Seção: Estudos.

\section{Educação escolar indígena}

BRUNO, Lúcia. Gestão da educação escolar indígena diferenciada: contradições, limites e possibilidades. RBEP, v. 92, n. 232, p. 639-662, set./dez. 2011. Seção: Estudos.

FREITAS, Marcos Antonio Braga de. O Instituto Insikiran da Universidade Federal de Roraima: trajetória das políticas para a educação superior indígena. RBEP, v. 92, n. 232, p. 599-615, set./dez. 2011. Seção: Estudos.

\section{Educação infantil}

BORGHI, Raquel Fontes; ADRIÃO, Theresa; GARCIA, Teise. As parcerias público-privadas para a oferta de vagas na educação infantil: um estudo em municípios paulistas. RBEP, v. 92, n. 231, p. 285-301, maio/ago. 2011. Seção: Estudos. 


\section{Educação no campo}

MARQUES, Waldemar; FRANCO, Fernando Silveira; SCHLINDWEIN, Marcelo Nivert. Universidade e movimentos sociais no Brasil: uma experiência de ação afirmativa. RBEP, v. 92, n. 232, p. 557-576, set./dez. 2011. Seção: Estudos.

\section{Educação superior}

BRUNO, Marilda Moraes Garcia. Políticas afirmativas para a inclusão do surdo no ensino superior: algumas reflexões sobre o acesso, a permanência e a cultura universitária. RBEP, v. 92, n. 232, p. 542-556, set./dez. 2011. Seção: Estudos.

VELLOSO, Jacques; CARDOSO, Claudete Batista. Um quinquênio de cotas: as chances de ingresso de negros na Universidade de Brasília. RBEP, v. 92, n. 231, p. 221-245, maio/ago. 2011. Seção: Estudos.

\section{educação, História da}

SANTOS, Valéria de Oliveira. A história da educação escrita por meio de práticas e ações pedagógicas. RBEP, v. 92, n. 230, p. 201-203, jan./abr. 2011. Seção: Resenhas.

\section{Educação, Historiografia da}

SILVA, José Cláudio Sooma; GONDRA, José Gonçalves. Textbooks in the History of Education: notas para pensar as narrativas de Paul Monroe, Stephen Duggan e Afranio Peixoto. RBEP, v. 92, n. 232, p. 702-722, set./ dez. 2011. Seção: Estudos.

\section{educação, Psicanálise em}

SIQUEIRA, Flávia Zanni. Psicanálise aplicada ao estudo do cotidiano escolar. RBEP, v. 92, n. 230, p. 187-199, jan./abr. 2011. Seção: Estudos.

\section{Educação, Sociologia da}

SOUSA, Letícia Pereira; PORTES, Écio Antônio. As propostas de políticas/ ações afirmativas das universidades públicas e as políticas/ações de permanência nos ordenamentos legais. RBEP, v. 92, n. 232, p. 516-541, set./dez. 2011. Seção: Estudos.

\section{educacionais, Desigualdades}

ROSISTOLATO, Rodrigo Pereira da Rocha. Juventudes populares em um pré-vestibular: a construção coletiva de expectativas e campos de possibilidades educacionais. RBEP, v. 92, n. 232, p. 616-638, set./dez. 2011. Seção: Estudos.

\section{educacional, Competência em matéria}

GOMES, Magno Federeci. Delimitação de atribuições educacionais: sistemas de ensino e competência constitucional. RBEP, v. 92, n. 230, p. 166-186, jan./abr. 2011. Seção: Estudos. 


\section{educacional, Direito}

GOMES, Magno Federeci. Delimitação de atribuições educacionais: sistemas de ensino e competência constitucional. RBEP, v. 92, n. 230, p. 166-186, jan./abr. 2011. Seção: Estudos.

\section{Efeitos de contrato}

ARAUJO, Lucia de Fátima; LIMA, Anna Paula de Avelar Brito; SANTOS, Marcelo Câmara dos. Ruptura e efeitos do contrato didático numa aula de resolução de problemas algébricos. RBEP, v. 92, n. 232, p. 739-756, set./dez. 2011. Seção: Estudos.

\section{EJA}

PEREIRA, Marcos Villela; FARE, Mónica de La. A formação de professores para Educação de Jovens e Adultos (EJA): as pesquisas na Argentina e no Brasil. RBEP, v. 92, n. 230, p. 70-82, jan./abr. 2011. Seção: Estudos.

\section{Emancipação}

AGOSTINHO, Luis Otávio Vincenzi; BREGA FILHO, Vladimir. Por um olhar democrático às ações afirmativas. RBEP, v. 92, n. 232, p. 455-476, set./ dez. 2011. Seção: Estudos.

\section{Ensino da escrita}

LEAL, Telma Ferraz; FERREIRA, Andrea Tereza Brito. Formação continuada e ensino da escrita: análise de estratégias formativas utilizadas no programa Pró-Letramento. RBEP, v. 92, n. 231, p. 370-385, maio/ago. 2011. Seção: Estudos.

\section{Ensino de História}

SILVA, José Cláudio Sooma; GONDRA, José Gonçalves. Textbooks in the History of Education: notas para pensar as narrativas de Paul Monroe, Stephen Duggan e Afranio Peixoto. RBEP, v. 92, n. 232, p. 702-722, set./ dez. 2011. Seção: Estudos.

\section{Ensino fundamental}

LIMA, Leonardo Claver Amorim. Da universalização do ensino fundamental ao desafio de democratizar o ensino médio em 2016: o que evidenciam as estatísticas? RBEP, v. 92, n. 231, p. 268-284, maio/ago. 2011. Seção: Estudos.

SILVA, Maria Helena G. Frem Dias da. Reinterpretando conceitos cristalizados com os professores: um degrau prévio para enfrentar os dilemas profissionais docentes. RBEP, v. 92, n. 231, p. 341-369, maio/ ago. 2011. Seção: Estudos.

\section{Ensino médio}

LIMA, Leonardo Claver Amorim. Da universalização do ensino fundamental ao desafio de democratizar o ensino médio em 2016: o que evidenciam 
as estatísticas? RBEP, v. 92, n. 231, p. 268-284, maio/ago. 2011. Seção: Estudos.

NEUBAUER, Rose (Coord.); DAVIS, Cláudia; TARTUCE, Gisela Lobo B. P.; NUNES, Marina M. R. Ensino médio no Brasil: uma análise de melhores práticas e de políticas públicas. RBEP, v. 92, n. 230, p. 11-33, jan./abr. 2011. Seção: Estudos.

PAGAN, Adriana; MAGINA, Sandra. O ensino de Estatística na educação básica com foco na interdisciplinaridade: um estudo comparativo. RBEP, v. 92, n. 232, p. 723-738, set./dez. 2011. Seção: Estudos.

\section{Ensino superior}

ROSISTOLATO, Rodrigo Pereira da Rocha. Juventudes populares em um pré-vestibular: a construção coletiva de expectativas e campos de possibilidades educacionais. RBEP, v. 92, n. 232, p. 616-638, set./dez. 2011. Seção: Estudos.

\section{ensino, Intervenção de}

PAGAN, Adriana; MAGINA, Sandra. O ensino de Estatística na educação básica com foco na interdisciplinaridade: um estudo comparativo. RBEP, v. 92, n. 232, p. 723-738, set./dez. 2011. Seção: Estudos.

\section{ensino, Metodologias de}

NEITZEL, Adair Aguiar; FERRI, Cássia. Formação continuada para professores da educação básica: metodologia do currículo integrado e laboratório de vivências pedagógicas. RBEP, v. 92, n. 230, p. 52-69, jan./ abr. 2011. Seção: Estudos.

ensino, Práticas de

SILVA, Sérgio Pereira da. Pedagogia do Ressentimento: o otimismo nas concepções e nas práticas de ensino. RBEP, v. 92, n. 230, p. 107-125, jan./ abr. 2011. Seção: Estudos.

\section{ensino, Sistemas de}

GOMES, Magno Federeci. Delimitação de atribuições educacionais: sistemas de ensino e competência constitucional. RBEP, v. 92, n. 230, p. 166-186, jan./abr. 2011. Seção: Estudos.

\section{entes federados, Atribuições específicas dos}

GOMES, Magno Federeci. Delimitação de atribuições educacionais: sistemas de ensino e competência constitucional. RBEP, v. 92, n. 230, p. 166-186, jan./abr. 2011. Seção: Estudos.

\section{Escola básica}

PEREIRA, Sueli Menezes; ZIENTARSKI, Clarice. Políticas de ações afirmativas e pobreza no Brasil. RBEP, v. 92, n. 232, p. 493-515, set./dez. 2011. Seção: Estudos. 


\section{Escola nova}

AZEVEDO, Fernanda Vicente de; BOMBASSARO, Ticiane; VAZ, Alexandre Fernandez. Escolarização do corpo e controle de si na revista Estudos Educacionais. RBEP, v. 92, n. 231, p. 302-315, maio/ago. 2011. Seção: Estudos.

\section{escolar, Cotidiano}

SIQUEIRA, Flávia Zanni. Psicanálise aplicada ao estudo do cotidiano escolar. RBEP, v. 92, n. 230, p. 187-199, jan./abr. 2011. Seção: Estudos.

\section{Escrita}

AlBUQUERQUE, Fernanda Medeiros de; GAliAZZI, Maria do Carmo. A formação do professor em rodas de formação. RBEP, v. 92, n. 231, p. 386398, maio/ago. 2011. Seção: Estudos.

SIQUEIRA, Idméa Semeghini. Recursos educacionais apropriados para recuperação lúdica do processo de letramento emergente. RBEP, v. 92, n. 230, p. 148-165, jan./abr. 2011. Seção: Estudos.

\section{escrita, Ensino da}

LEAL, Telma Ferraz; FERREIRA, Andrea Tereza Brito. Formação continuada e ensino da escrita: análise de estratégias formativas utilizadas no programa Pró-Letramento. RBEP, v. 92, n. 231, p. 370-385, maio/ago. 2011. Seção: Estudos.

\section{Escritas da História}

SILVA, José Cláudio Sooma; GONDRA, José Gonçalves. Textbooks in the History of Education: notas para pensar as narrativas de Paul Monroe, Stephen Duggan e Afranio Peixoto. RBEP, v. 92, n. 232, p. 702-722, set./ dez. 2011. Seção: Estudos.

\section{Estado}

VOLPATO, Gildo. A universidade na sua constituição: criação, reformas e implicações político-epistemológicas. RBEP, v. 92, n. 232, p. 678-701, set./dez. 2011. Seção: Estudos.

\section{estudante, Condição de}

ÁVILA, Rebeca Contrera. Estudantes de camadas populares e o ingresso na vida universitária. RBEP, v. 92, n. 232, p. 757-764, set./dez. 2011. Seção: Resenhas.

\section{Estudo longitudinal}

FACCENDA, Odival; DALBEN, Adilson; FREITAS, Luiz Carlos de. Capacidade explicativa de questionários de contexto: aspectos metodológicos. RBEP, v. 92, n. 231, p. 246-267, maio/ago. 2011. Seção: Estudos. 


\section{Formação}

CESTARI, Luiz Artur Santos. Autobiografias e formação: aproximações problemáticas no Movimento Pesquisa/Formação. RBEP, v. 92, n. 230, p. 83-106, jan./abr. 2011. Seção: Estudos.

\section{Formação continuada}

LEAL, Telma Ferraz; FERREIRA, Andrea Tereza Brito. Formação continuada e ensino da escrita: análise de estratégias formativas utilizadas no programa Pró-Letramento. RBEP, v. 92, n. 231, p. 370-385, maio/ago. 2011. Seção: Estudos.

\section{Formação de adultos}

MARTINS, Regina Maria Caruccio. Discussão em torno da noção de acompanhamento de jovens adultos na educação superior. RBEP, v. 92, n. 231, p. 417-433, maio/ago. 2011. Seção: Estudos.

\section{Formação de professores}

ALBUQUERQUE, Fernanda Medeiros de; GALIAZZI, Maria do Carmo. A formação do professor em rodas de formação. RBEP, v. 92, n. 231, p. 386398, maio/ago. 2011. Seção: Estudos.

NEITZEL, Adair Aguiar; FERRI, Cássia. Formação continuada para professores da educação básica: metodologia do currículo integrado e laboratório de vivências pedagógicas. RBEP, v. 92, n. 230, p. 52-69, jan./ abr. 2011. Seção: Estudos.

PEREIRA, Júlio Emílio Diniz. O ovo ou a galinha: a crise da profissão docente e a aparente falta de perspectiva para a educação brasileira. RBEP, v. 92, n. 230, p. 34-51, jan./abr. 2011. Seção: Estudos.

\section{Formação profissional}

MARTINS, Regina Maria Caruccio. Discussão em torno da noção de acompanhamento de jovens adultos na educação superior. RBEP, v. 92, n. 231, p. 417-433, maio/ago. 2011. Seção: Estudos.

\section{Formação social}

PEREIRA, Sueli Menezes; ZIENTARSKI, Clarice. Políticas de ações afirmativas e pobreza no Brasil. RBEP, v. 92, n. 232, p. 493-515, set./dez. 2011. Seção: Estudos.

\section{Gestão}

BRUNO, Lúcia. Gestão da educação escolar indígena diferenciada: contradições, limites e possibilidades. RBEP, v. 92, n. 232, p. 639-662, set./dez. 2011. Seção: Estudos.

\section{gráficos e tabelas, Construção e interpretação de}

PAGAN, Adriana; MAGINA, Sandra. O ensino de Estatística na educação básica com foco na interdisciplinaridade: um estudo comparativo. RBEP, v. 92, n. 232, p. 723-738, set./dez. 2011. Seção: Estudos. 


\section{História da educação}

SANTOS, Valéria de Oliveira. A história da educação escrita por meio de práticas e ações pedagógicas. RBEP, v. 92, n. 230, p. 201-203, jan./abr. 2011. Seção: Resenhas.

\section{História, Ensino de}

SILVA, José Cláudio Sooma; GONDRA, José Gonçalves. Textbooks in the History of Education: notas para pensar as narrativas de Paul Monroe, Stephen Duggan e Afranio Peixoto. RBEP, v. 92, n. 232, p. 702-722, set./ dez. 2011. Seção: Estudos.

\section{História, Escritas da}

SILVA, José Cláudio Sooma; GONDRA, José Gonçalves. Textbooks in the History of Education: notas para pensar as narrativas de Paul Monroe, Stephen Duggan e Afranio Peixoto. RBEP, v. 92, n. 232, p. 702-722, set./ dez. 2011. Seção: Estudos.

\section{Historiografia da Educação}

SILVA, José Cláudio Sooma; GONDRA, José Gonçalves. Textbooks in the History of Education: notas para pensar as narrativas de Paul Monroe, Stephen Duggan e Afranio Peixoto. RBEP, v. 92, n. 232, p. 702-722, set./ dez. 2011. Seção: Estudos.

\section{Igualdade racial}

AGOSTINHO, Luis Otávio Vincenzi; BREGA FILHO, Vladimir. Por um olhar democrático às ações afirmativas. RBEP, v. 92, n. 232, p. 455-476, set./ dez. 2011. Seção: Estudos.

\section{Imaginário intercultural}

BARBOSA, Manuel Gonçalves. Educação e imaginário intercultural: recomposição do papel da sociedade civil. RBEP, v. 92, n. 232, p. 477-492, set./dez. 2011. Seção: Estudos.

\section{Inclusão e cultura universitária}

BRUNO, Marilda Moraes Garcia. Políticas afirmativas para a inclusão do surdo no ensino superior: algumas reflexões sobre o acesso, a permanência e a cultura universitária. RBEP, v. 92, n. 232, p. 542-556, set./dez. 2011. Seção: Estudos.

\section{Indicadores oficiais}

LIMA, Leonardo Claver Amorim. Da universalização do ensino fundamental ao desafio de democratizar o ensino médio em 2016: o que evidenciam as estatísticas? RBEP, v. 92, n. 231, p. 268-284, maio/ago. 2011. Seção: Estudos.

\section{indígena, Educação escolar}

BRUNO, Lúcia. Gestão da educação escolar indígena diferenciada: 
contradições, limites e possibilidades. RBEP, v. 92, n. 232, p. 639-662, set./dez. 2011. Seção: Estudos.

FREITAS, Marcos Antonio Braga de. O Instituto Insikiran da Universidade Federal de Roraima: trajetória das políticas para a educação superior indígena. RBEP, v. 92, n. 232, p. 599-615, set./dez. 2011. Seção: Estudos.

\section{indígena, Movimento}

FREITAS, Marcos Antonio Braga de. O Instituto Insikiran da Universidade Federal de Roraima: trajetória das políticas para a educação superior indígena. RBEP, v. 92, n. 232, p. 599-615, set./dez. 2011. Seção: Estudos.

\section{ingresso, Chances de}

VELLOSO, Jacques; CARDOSO, Claudete Batista. Um quinquênio de cotas: as chances de ingresso de negros na Universidade de Brasília. RBEP, v. 92, n. 231, p. 221-245, maio/ago. 2011. Seção: Estudos.

\section{intercultural, Imaginário}

BARBOSA, Manuel Gonçalves. Educação e imaginário intercultural: recomposição do papel da sociedade civil. RBEP, v. 92, n. 232, p. 477-492, set./dez. 2011. Seção: Estudos.

\section{Interdisciplinaridade}

PAGAN, Adriana; MAGINA, Sandra. O ensino de Estatística na educação básica com foco na interdisciplinaridade: um estudo comparativo. RBEP, v. 92, n. 232, p. 723-738, set./dez. 2011. Seção: Estudos.

\section{Juventudes}

ROSISTOLATO, Rodrigo Pereira da Rocha. Juventudes populares em um pré-vestibular: a construção coletiva de expectativas e campos de possibilidades educacionais. RBEP, v. 92, n. 232, p. 616-638, set./dez. 2011. Seção: Estudos.

\section{Leitura}

SIQUEIRA, Idméa Semeghini. Recursos educacionais apropriados para recuperação lúdica do processo de letramento emergente. RBEP, v. 92, n. 230, p. 148-165, jan./abr. 2011. Seção: Estudos.

\section{Letramento}

CRUZ, Magna Silva; ALBUQUERQUE, Eliana Borges. Alfabetização e letramento no $1^{\circ}$ ciclo: o que as crianças aprendem sobre a escrita a cada ano? RBEP, v. 92, n. 230, p. 126-147, jan./abr. 2011. Seção: Estudos.

SIQUEIRA, Idméa Semeghini. Recursos educacionais apropriados para recuperação lúdica do processo de letramento emergente. RBEP, v. 92, n. 230, p. 148-165, jan./abr. 2011. Seção: Estudos. 


\section{Licenciaturas}

PEREIRA, Júlio Emílio Diniz. O ovo ou a galinha: a crise da profissão docente e a aparente falta de perspectiva para a educação brasileira. RBEP, v. 92, n. 230, p. 34-51, jan./abr. 2011. Seção: Estudos.

\section{longitudinal, Estudo}

FACCENDA, Odival; DALBEN, Adilson; FREITAS, Luiz Carlos de. Capacidade explicativa de questionários de contexto: aspectos metodológicos. RBEP, v. 92, n. 231, p. 246-267, maio/ago. 2011. Seção: Estudos.

\section{Ludicidade}

SIQUEIRA, Idméa Semeghini. Recursos educacionais apropriados para recuperação lúdica do processo de letramento emergente. RBEP, v. 92, n. 230, p. 148-165, jan./abr. 2011. Seção: Estudos.

\section{matéria educacional, Competência em}

GOMES, Magno Federeci. Delimitação de atribuições educacionais: sistemas de ensino e competência constitucional. RBEP, v. 92, n. 230, p. 166-186, jan./abr. 2011. Seção: Estudos.

\section{Melhores práticas}

NEUBAUER, Rose (Coord.); DAVIS, Cláudia; TARTUCE, Gisela Lobo B. P.; NUNES, Marina M. R. Ensino médio no Brasil: uma análise de melhores práticas e de políticas públicas. RBEP, v. 92, n. 230, p. 11-33, jan./abr. 2011. Seção: Estudos.

\section{Metas}

CRUZ, Magna Silva; ALBUQUERQUE, Eliana Borges. Alfabetização e letramento no $1^{\circ}$ ciclo: o que as crianças aprendem sobre a escrita a cada ano? RBEP, v. 92, n. 230, p. 126-147, jan./abr. 2011. Seção: Estudos.

\section{método, Relação conteúdo-}

NEITZEL, Adair Aguiar; FERRI, Cássia. Formação continuada para professores da educação básica: metodologia do currículo integrado e laboratório de vivências pedagógicas. RBEP, v. 92, n. 230, p. 52-69, jan./ abr. 2011. Seção: Estudos.

\section{Metodologia de pesquisa colaborativa}

SILVA, Maria Helena G. Frem Dias da. Reinterpretando conceitos cristalizados com os professores: um degrau prévio para enfrentar os dilemas profissionais docentes. RBEP, v. 92, n. 231, p. 341-369, maio/ ago. 2011. Seção: Estudos.

\section{Metodologias de ensino}

NEITZEL, Adair Aguiar; FERRI, Cássia. Formação continuada para professores da educação básica: metodologia do currículo integrado e laboratório de vivências pedagógicas. RBEP, v. 92, n. 230, p. 52-69, jan./ abr. 2011. Seção: Estudos. 


\section{Mitos de fundação}

ROIZ, Diogo da Silva. Dos mitos de fundação às práticas políticas: os projetos de usos do passado em questão. RBEP, v. 92, n. 232, p. 765-769, set./dez. 2011. Seção: Resenhas.

\section{Movimento}

CESTARI, Luiz Artur Santos. Autobiografias e formação: aproximações problemáticas no Movimento Pesquisa/Formação. RBEP, v. 92, n. 230, p. 83-106, jan./abr. 2011. Seção: Estudos.

\section{Movimento indígena}

FREITAS, Marcos Antonio Braga de. O Instituto Insikiran da Universidade Federal de Roraima: trajetória das políticas para a educação superior indígena. RBEP, v. 92, n. 232, p. 599-615, set./dez. 2011. Seção: Estudos.

\section{Movimentos sociais}

MARQUES, Waldemar; FRANCO, Fernando Silveira; SCHLINDWEIN, Marcelo Nivert. Universidade e movimentos sociais no Brasil: uma experiência de ação afirmativa. RBEP, v. 92, n. 232, p. 557-576, set./dez. 2011. Seção: Estudos.

\section{multivariada, Análise}

FACCENDA, Odival; DALBEN, Adilson; FREITAS, Luiz Carlos de. Capacidade explicativa de questionários de contexto: aspectos metodológicos. RBEP, v. 92, n. 231, p. 246-267, maio/ago. 2011. Seção: Estudos.

\section{Otimismo}

SILVA, Sérgio Pereira da. Pedagogia do Ressentimento: o otimismo nas concepções e nas práticas de ensino. RBEP, v. 92, n. 230, p. 107-125, jan./ abr. 2011. Seção: Estudos.

\section{Parcerias}

BORGHI, Raquel Fontes; ADRIÃO, Theresa; GARCIA, Teise. As parcerias público-privadas para a oferta de vagas na educação infantil: um estudo em municípios paulistas. RBEP, v. 92, n. 231, p. 285-301, maio/ago. 2011. Seção: Estudos.

\section{Pedagogia}

SILVA, Sérgio Pereira da. Pedagogia do Ressentimento: o otimismo nas concepções e nas práticas de ensino. RBEP, v. 92, n. 230, p. 107-125, jan./ abr. 2011. Seção: Estudos.

\section{pedagogia, Curso de}

NEITZEL, Adair Aguiar; FERRI, Cássia. Formação continuada para professores da educação básica: metodologia do currículo integrado e laboratório de vivências pedagógicas. RBEP, v. 92, n. 230, p. 52-69, jan./ abr. 2011. Seção: Estudos. 


\section{pesquisa colaborativa, Metodologia de}

SILVA, Maria Helena G. Frem Dias da. Reinterpretando conceitos cristalizados com os professores: um degrau prévio para enfrentar os dilemas profissionais docentes. RBEP, v. 92, n. 231, p. 341-369, maio/ ago. 2011. Seção: Estudos.

\section{Pesquisa psicológica}

SIQUEIRA, Flávia Zanni. Psicanálise aplicada ao estudo do cotidiano escolar. RBEP, v. 92, n. 230, p. 187-199, jan./abr. 2011. Seção: Estudos.

\section{Pessimismo}

SILVA, Sérgio Pereira da. Pedagogia do Ressentimento: o otimismo nas concepções e nas práticas de ensino. RBEP, v. 92, n. 230, p. 107-125, jan./ abr. 2011. Seção: Estudos.

\section{Pobreza}

PEREIRA, Sueli Menezes; ZIENTARSKI, Clarice. Políticas de ações afirmativas e pobreza no Brasil. RBEP, v. 92, n. 232, p. 493-515, set./dez. 2011. Seção: Estudos.

\section{Política governamental}

SOUSA, Letícia Pereira; PORTES, Écio Antônio. As propostas de políticas/ ações afirmativas das universidades públicas e as políticas/ações de permanência nos ordenamentos legais. RBEP, v. 92, n. 232, p. 516-541, set./dez. 2011. Seção: Estudos.

\section{política, Ação}

SOUSA, Letícia Pereira; PORTES, Écio Antônio. As propostas de políticas/ ações afirmativas das universidades públicas e as políticas/ações de permanência nos ordenamentos legais. RBEP, v. 92, n. 232, p. 516-541, set./dez. 2011. Seção: Estudos.

\section{Políticas}

VOLPATO, Gildo. A universidade na sua constituição: criação, reformas e implicações político-epistemológicas. RBEP, v. 92, n. 232, p. 678-701, set./dez. 2011. Seção: Estudos.

\section{Políticas públicas}

FREITAS, Marcos Antonio Braga de. O Instituto Insikiran da Universidade Federal de Roraima: trajetória das políticas para a educação superior indígena. RBEP, v. 92, n. 232, p. 599-615, set./dez. 2011. Seção: Estudos.

NEUBAUER, Rose (Coord.); DAVIS, Cláudia; TARTUCE, Gisela Lobo B. P.; NUNES, Marina M. R. Ensino médio no Brasil: uma análise de melhores práticas e de políticas públicas. RBEP, v. 92, n. 230, p. 11-33, jan./abr. 2011. Seção: Estudos. 


\section{políticas, Práticas}

ROIZ, Diogo da Silva. Dos mitos de fundação às práticas políticas: os projetos de usos do passado em questão. RBEP, v. 92, n. 232, p. 765-769, set./dez. 2011. Seção: Resenhas.

\section{popular, Cultura}

MOURA, Eliana P. G. de; ZUCCHETTI, Dinora Tereza; MENEZES, Magali Mendes de. Cultura e resistência: a criação do popular e o popular como criação. RBEP, v. 92, n. 232, p. 663-677, set./dez. 2011. Seção: Estudos.

\section{Práticas de ensino}

SILVA, Sérgio Pereira da. Pedagogia do Ressentimento: o otimismo nas concepções e nas práticas de ensino. RBEP, v. 92, n. 230, p. 107-125, jan./ abr. 2011. Seção: Estudos.

\section{práticas, Melhores}

NEUBAUER, Rose (Coord.); DAVIS, Cláudia; TARTUCE, Gisela Lobo B. P.; NUNES, Marina M. R. Ensino médio no Brasil: uma análise de melhores práticas e de políticas públicas. RBEP, v. 92, n. 230, p. 11-33, jan./abr. 2011. Seção: Estudos.

\section{Práticas políticas}

ROIZ, Diogo da Silva. Dos mitos de fundação às práticas políticas: os projetos de usos do passado em questão. RBEP, v. 92, n. 232, p. 765-769, set./dez. 2011. Seção: Resenhas.

\section{problemas algébricos, Resolução de}

ARAUJO, Lucia de Fátima; LIMA, Anna Paula de Avelar Brito; SANTOS, Marcelo Câmara dos. Ruptura e efeitos do contrato didático numa aula de resolução de problemas algébricos. RBEP, v. 92, n. 232, p. 739-756, set./dez. 2011. Seção: Estudos.

\section{Produção de textos}

LEAL, Telma Ferraz; FERREIRA, Andrea Tereza Brito. Formação continuada e ensino da escrita: análise de estratégias formativas utilizadas no programa Pró-Letramento. RBEP, v. 92, n. 231, p. 370-385, maio/ago. 2011. Seção: Estudos.

\section{Professores}

OSÓRIO, Mara Rejane Vieira. Professores e Educação Ambiental: implicações para o currículo. RBEP, v. 92, n. 231, p. 399-416, maio/ago. 2011. Seção: Estudos.

SILVA, Maria Helena G. Frem Dias da. Reinterpretando conceitos cristalizados com os professores: um degrau prévio para enfrentar os dilemas profissionais docentes. RBEP, v. 92, n. 231, p. 341-369, maio/ ago. 2011. Seção: Estudos. 


\section{professores, Formação de}

ALBUQUERQUE, Fernanda Medeiros de; GALIAZZI, Maria do Carmo. A formação do professor em rodas de formação. RBEP, v. 92, n. 231, p. 386398, maio/ago. 2011. Seção: Estudos.

NEITZEL, Adair Aguiar; FERRI, Cássia. Formação continuada para professores da educação básica: metodologia do currículo integrado e laboratório de vivências pedagógicas. RBEP, v. 92, n. 230, p. 52-69, jan./ abr. 2011. Seção: Estudos.

PEREIRA, Júlio Emílio Diniz. O ovo ou a galinha: a crise da profissão docente e a aparente falta de perspectiva para a educação brasileira. RBEP, v. 92, n. 230, p. 34-51, jan./abr. 2011. Seção: Estudos.

\section{profissional, Formação}

MARTINS, Regina Maria Caruccio. Discussão em torno da noção de acompanhamento de jovens adultos na educação superior. RBEP, v. 92, n. 231, p. 417-433, maio/ago. 2011. Seção: Estudos.

\section{Pronera}

MARQUES, Waldemar; FRANCO, Fernando Silveira; SCHLINDWEIN, Marcelo Nivert. Universidade e movimentos sociais no Brasil: uma experiência de ação afirmativa. RBEP, v. 92, n. 232, p. 557-576, set./dez. 2011. Seção: Estudos.

\section{Psicanálise em educação}

SIQUEIRA, Flávia Zanni. Psicanálise aplicada ao estudo do cotidiano escolar. RBEP, v. 92, n. 230, p. 187-199, jan./abr. 2011. Seção: Estudos.

\section{públicas, Políticas}

FREITAS, Marcos Antonio Braga de. O Instituto Insikiran da Universidade Federal de Roraima: trajetória das políticas para a educação superior indígena. RBEP, v. 92, n. 232, p. 599-615, set./dez. 2011. Seção: Estudos.

NEUBAUER, Rose (Coord.); DAVIS, Cláudia; TARTUCE, Gisela Lobo B. P.; NUNES, Marina M. R. Ensino médio no Brasil: uma análise de melhores práticas e de políticas públicas. RBEP, v. 92, n. 230, p. 11-33, jan./abr. 2011. Seção: Estudos.

\section{Público-privado}

BORGHI, Raquel Fontes; ADRIÃO, Theresa; GARCIA, Teise. As parcerias público-privadas para a oferta de vagas na educação infantil: um estudo em municípios paulistas. RBEP, v. 92, n. 231, p. 285-301, maio/ago. 2011. Seção: Estudos.

\section{Quinta a $8^{\mathrm{a}}$ série}

SILVA, Maria Helena G. Frem Dias da. Reinterpretando conceitos cristalizados com os professores: um degrau prévio para enfrentar os 
dilemas profissionais docentes. RBEP, v. 92, n. 231, p. 341-369, maio/ ago. 2011. Seção: Estudos.

racial, Igualdade

AGOSTINHO, Luis Otávio Vincenzi; BREGA FILHO, Vladimir. Por um olhar democrático às ações afirmativas. RBEP, v. 92, n. 232, p. 455-476, set./ dez. 2011. Seção: Estudos.

\section{Racismo}

AGOSTINHO, Luis Otávio Vincenzi; BREGA FILHO, Vladimir. Por um olhar democrático às ações afirmativas. RBEP, v. 92, n. 232, p. 455-476, set./ dez. 2011. Seção: Estudos.

DOEBBER, Michele Barcelos; GRISA, Gregório Durlo. Ações afirmativas: o critério racial e a experiência da Universidade Federal do Rio Grande do Sul. RBEP, v. 92, n. 232, p. 577-598, set./dez. 2011. Seção: Estudos.

\section{Recursos didáticos}

SIQUEIRA, Idméa Semeghini. Recursos educacionais apropriados para recuperação lúdica do processo de letramento emergente. RBEP, v. 92, n. 230, p. 148-165, jan./abr. 2011. Seção: Estudos.

\section{Reforma agrária}

MARQUES, Waldemar; FRANCO, Fernando Silveira; SCHLINDWEIN, Marcelo Nivert. Universidade e movimentos sociais no Brasil: uma experiência de ação afirmativa. RBEP, v. 92, n. 232, p. 557-576, set./dez. 2011. Seção: Estudos.

\section{Reformas}

VOLPATO, Gildo. A universidade na sua constituição: criação, reformas e implicações político-epistemológicas. RBEP, v. 92, n. 232, p. 678-701, set./dez. 2011. Seção: Estudos.

\section{Relação conteúdo-método}

NEITZEL, Adair Aguiar; FERRI, Cássia. Formação continuada para professores da educação básica: metodologia do currículo integrado e laboratório de vivências pedagógicas. RBEP, v. 92, n. 230, p. 52-69, jan./ abr. 2011. Seção: Estudos.

\section{Relações intergeracionais}

BUENO, Fabrício Aparecido; SANT'ANA, Ruth Bernardes de. A experiência geracional na fala de alunos de escola pública: a questão da autoridade docente. RBEP, v. 92, n. 231, p. 316-340, maio/ago. 2011. Seção: Estudos.

\section{Resistência}

MOURA, Eliana P. G. de; ZUCCHETTI, Dinora Tereza; MENEZES, Magali Mendes de. Cultura e resistência: a criação do popular e o popular como criação. RBEP, v. 92, n. 232, p. 663-677, set./dez. 2011. Seção: Estudos. 


\section{Resolução de problemas algébricos}

ARAUJO, Lucia de Fátima; LIMA, Anna Paula de Avelar Brito; SANTOS, Marcelo Câmara dos. Ruptura e efeitos do contrato didático numa aula de resolução de problemas algébricos. RBEP, v. 92, n. 232, p. 739-756, set./dez. 2011. Seção: Estudos.

\section{Ressentimento}

SILVA, Sérgio Pereira da. Pedagogia do Ressentimento: o otimismo nas concepções e nas práticas de ensino. RBEP, v. 92, n. 230, p. 107-125, jan./ abr. 2011. Seção: Estudos.

\section{Saber docente}

SILVA, Maria Helena G. Frem Dias da. Reinterpretando conceitos cristalizados com os professores: um degrau prévio para enfrentar os dilemas profissionais docentes. RBEP, v. 92, n. 231, p. 341-369, maio/ ago. 2011. Seção: Estudos.

\section{Sistema de ciclos}

CRUZ, Magna Silva; ALBUQUERQUE, Eliana Borges. Alfabetização e letramento no $1^{\circ}$ ciclo: o que as crianças aprendem sobre a escrita a cada ano? RBEP, v. 92, n. 230, p. 126-147, jan./abr. 2011. Seção: Estudos.

\section{Sistema de cotas}

VELLOSO, Jacques; CARDOSO, Claudete Batista. Um quinquênio de cotas: as chances de ingresso de negros na Universidade de Brasília. RBEP, v. 92, n. 231, p. 221-245, maio/ago. 2011. Seção: Estudos.

\section{Sistemas de ensino}

GOMES, Magno Federeci. Delimitação de atribuições educacionais: sistemas de ensino e competência constitucional. RBEP, v. 92, n. 230, p. 166-186, jan./abr. 2011. Seção: Estudos.

\section{social, Formação}

PEREIRA, Sueli Menezes; ZIENTARSKI, Clarice. Políticas de ações afirmativas e pobreza no Brasil. RBEP, v. 92, n. 232, p. 493-515, set./dez. 2011. Seção: Estudos.

\section{Sociedade civil}

BARBOSA, Manuel Gonçalves. Educação e imaginário intercultural: recomposição do papel da sociedade civil. RBEP, v. 92, n. 232, p. 477-492, set./dez. 2011. Seção: Estudos.

\section{Sociologia da Educação}

SOUSA, Letícia Pereira; PORTES, Écio Antônio. As propostas de políticas/ ações afirmativas das universidades públicas e as políticas/ações de permanência nos ordenamentos legais. RBEP, v. 92, n. 232, p. 516-541, set./dez. 2011. Seção: Estudos. 


\section{Surdez}

BRUNO, Marilda Moraes Garcia. Políticas afirmativas para a inclusão do surdo no ensino superior: algumas reflexões sobre o acesso, a permanência e a cultura universitária. RBEP, v. 92, n. 232, p. 542-556, set./dez. 2011. Seção: Estudos.

\section{Survey}

FACCENDA, Odival; DALBEN, Adilson; FREITAS, Luiz Carlos de. Capacidade explicativa de questionários de contexto: aspectos metodológicos. RBEP, v. 92, n. 231, p. 246-267, maio/ago. 2011. Seção: Estudos.

\section{tabelas, Construção e interpretação de gráficos e}

PAGAN, Adriana; MAGINA, Sandra. O ensino de Estatística na educação básica com foco na interdisciplinaridade: um estudo comparativo. RBEP, v. 92, n. 232, p. 723-738, set./dez. 2011. Seção: Estudos.

\section{textos, Produção de}

LEAL, Telma Ferraz; FERREIRA, Andrea Tereza Brito. Formação continuada e ensino da escrita: análise de estratégias formativas utilizadas no programa Pró-Letramento. RBEP, v. 92, n. 231, p. 370-385, maio/ago. 2011. Seção: Estudos.

\section{Universidade}

DOEBBER, Michele Barcelos; GRISA, Gregório Durlo. Ações afirmativas: o critério racial e a experiência da Universidade Federal do Rio Grande do Sul. RBEP, v. 92, n. 232, p. 577-598, set./dez. 2011. Seção: Estudos.

VOLPATO, Gildo. A universidade na sua constituição: criação, reformas e implicações político-epistemológicas. RBEP, v. 92, n. 232, p. 678-701, set./dez. 2011. Seção: Estudos.

\section{Universidade de Brasília}

VELLOSO, Jacques; CARDOSO, Claudete Batista. Um quinquênio de cotas: as chances de ingresso de negros na Universidade de Brasília. RBEP, v. 92, n. 231, p. 221-245, maio/ago. 2011. Seção: Estudos.

\section{universitária, Inclusão e cultura}

BRUNO, Marilda Moraes Garcia. Políticas afirmativas para a inclusão do surdo no ensino superior: algumas reflexões sobre o acesso, a permanência e a cultura universitária. RBEP, v. 92, n. 232, p. 542-556, set./dez. 2011. Seção: Estudos.

\section{universitária, Vida}

ÁVILA, Rebeca Contrera. Estudantes de camadas populares e o ingresso na vida universitária. RBEP, v. 92, n. 232, p. 757-764, set./dez. 2011. Seção: Resenhas. 


\section{Vida}

MOURA, Eliana P. G. de; ZUCCHETTI, Dinora Tereza; MENEZES, Magali Mendes de. Cultura e resistência: a criação do popular e o popular como criação. RBEP, v. 92, n. 232, p. 663-677, set./dez. 2011. Seção: Estudos.

\section{Vida universitária}

ÁVILA, Rebeca Contrera. Estudantes de camadas populares e o ingresso na vida universitária. RBEP, v. 92, n. 232, p. 757-764, set./dez. 2011. Seção: Resenhas. 


\section{ÍNDICE DE AUTORES RBEP}

ADRIÃO, Theresa; BORGHI, Raquel Fontes; GARCIA, Teise. As parcerias público-privadas para a oferta de vagas na educação infantil: um estudo em municípios paulistas. RBEP, v. 92, n. 231, p. 285-301, maio/ago. 2011. Seção: Estudos.

AGOSTINHO, Luis Otávio Vincenzi; BREGA FILHO, Vladimir. Por um olhar democrático às ações afirmativas. RBEP, v. 92, n. 232, p. 455-476, set./ dez. 2011. Seção: Estudos.

ALBUQUERQUE, Eliana Borges; CRUZ, Magna Silva. Alfabetização e letramento no $1^{\circ}$ ciclo: o que as crianças aprendem sobre a escrita a cada ano? RBEP, v. 92, n. 230, p. 126-147, jan./abr. 2011. Seção: Estudos.

ALBUQUERQUE, Fernanda Medeiros de; GALIAZZI, Maria do Carmo. A formação do professor em rodas de formação. RBEP, v. 92, n. 231, p. 386398, maio/ago. 2011. Seção: Estudos.

ARAUJO, Lucia de Fátima; LIMA, Anna Paula de Avelar Brito; SANTOS, Marcelo Câmara dos. Ruptura e efeitos do contrato didático numa aula de resolução de problemas algébricos. RBEP, v. 92, n. 232, p. 739-756, set./dez. 2011. Seção: Estudos. 
ÁVILA, Rebeca Contrera. Estudantes de camadas populares e o ingresso na vida universitária. RBEP, v. 92, n. 232, p. 757-764, set./dez. 2011. Seção: Resenhas.

AZEVEDO, Fernanda Vicente de; BOMBASSARO, Ticiane; VAZ, Alexandre Fernandez. Escolarização do corpo e controle de si na revista Estudos Educacionais. RBEP, v. 92, n. 231, p. 302-315, maio/ago. 2011. Seção: Estudos.

BARBOSA, Manuel Gonçalves. Educação e imaginário intercultural: recomposição do papel da sociedade civil. RBEP, v. 92, n. 232, p. 477-492, set./dez. 2011. Seção: Estudos.

BOMBASSARO, Ticiane; AZEVEDO, Fernanda Vicente de; VAZ, Alexandre Fernandez. Escolarização do corpo e controle de si na revista Estudos Educacionais. RBEP, v. 92, n. 231, p. 302-315, maio/ago. 2011. Seção: Estudos.

BORGHI, Raquel Fontes; ADRIÃO, Theresa; GARCIA, Teise. As parcerias público-privadas para a oferta de vagas na educação infantil: um estudo em municípios paulistas. RBEP, v. 92, n. 231, p. 285-301, maio/ago. 2011. Seção: Estudos.

BREGA FILHO, Vladimir; AGOSTINHO, Luis Otávio Vincenzi. Por um olhar democrático às ações afirmativas. RBEP, v. 92, n. 232, p. 455-476, set./ dez. 2011. Seção: Estudos.

BRUNO, Lúcia. Gestão da educação escolar indígena diferenciada: contradições, limites e possibilidades. RBEP, v. 92, n. 232, p. 639-662, set./dez. 2011. Seção: Estudos.

BRUNO, Marilda Moraes Garcia. Políticas afirmativas para a inclusão do surdo no ensino superior: algumas reflexões sobre o acesso, a permanência e a cultura universitária. RBEP, v. 92, n. 232, p. 542-556, set./dez. 2011. Seção: Estudos.

BUENO, Fabrício Aparecido; SANT'ANA, Ruth Bernardes de. A experiência geracional na fala de alunos de escola pública: a questão da autoridade docente. RBEP, v. 92, n. 231, p. 316-340, maio/ago. 2011. Seção: Estudos.

CARDOSO, Claudete Batista; VELLOSO, Jacques. Um quinquênio de cotas: as chances de ingresso de negros na Universidade de Brasília. RBEP, v. 92, n. 231, p. 221-245, maio/ago. 2011. Seção: Estudos.

CESTARI, Luiz Artur Santos. Autobiografias e formação: aproximações problemáticas no Movimento Pesquisa/Formação. RBEP, v. 92, n. 230, p. 83-106, jan./abr. 2011. Seção: Estudos. 
CRUZ, Magna Silva; ALBUQUERQUE, Eliana Borges. Alfabetização e letramento no $1^{\circ}$ ciclo: o que as crianças aprendem sobre a escrita a cada ano? RBEP, v. 92, n. 230, p. 126-147, jan./abr. 2011. Seção: Estudos.

DALBEN, Adilson; FACCENDA, Odival; FREITAS, Luiz Carlos de. Capacidade explicativa de questionários de contexto: aspectos metodológicos. RBEP, v. 92, n. 231, p. 246-267, maio/ago. 2011. Seção: Estudos.

DAVIS, Cláudia; NEUBAUER, Rose (Coord.); TARTUCE, Gisela Lobo B. P.; NUNES, Marina M. R. Ensino médio no Brasil: uma análise de melhores práticas e de políticas públicas. RBEP, v. 92, n. 230, p. 11-33, jan./abr. 2011. Seção: Estudos.

DOEBBER, Michele Barcelos; GRISA, Gregório Durlo. Ações afirmativas: o critério racial e a experiência da Universidade Federal do Rio Grande do Sul. RBEP, v. 92, n. 232, p. 577-598, set./dez. 2011. Seção: Estudos.

EDITORIA CIENTÍFICA. [Editorial]. RBEP, v. 92, n. 230, p. 9-10, jan./abr. 2011. Seção: Editorial.

EDITORIA CIENTÍFICA. [Editorial]. RBEP, v. 92, n. 231, p. 219-220, maio/ ago. 2011. Seção: Editorial.

EDITORIA CIENTÍFICA. [Editorial]. RBEP, v. 92, n. 232, p. 453-454, set./ dez. 2011. Seção: Editorial.

FACCENDA, Odival; DALBEN, Adilson; FREITAS, Luiz Carlos de. Capacidade explicativa de questionários de contexto: aspectos metodológicos. RBEP, v. 92, n. 231, p. 246-267, maio/ago. 2011. Seção: Estudos.

FARE, Mónica de La; PEREIRA, Marcos Villela. A formação de professores para Educação de Jovens e Adultos (EJA): as pesquisas na Argentina e no Brasil. RBEP, v. 92, n. 230, p. 70-82, jan./abr. 2011. Seção: Estudos.

FERREIRA, Andrea Tereza Brito; LEAL, Telma Ferraz. Formação continuada e ensino da escrita: análise de estratégias formativas utilizadas no programa Pró-Letramento. RBEP, v. 92, n. 231, p. 370-385, maio/ago. 2011. Seção: Estudos.

FERRI, Cássia; NEITZEL, Adair Aguiar. Formação continuada para professores da educação básica: metodologia do currículo integrado e laboratório de vivências pedagógicas. RBEP, v. 92, n. 230, p. 52-69, jan./ abr. 2011. Seção: Estudos.

FRANCO, Fernando Silveira; MARQUES, Waldemar; SCHLINDWEIN, Marcelo Nivert. Universidade e movimentos sociais no Brasil: uma 
experiência de ação afirmativa. RBEP, v. 92, n. 232, p. 557-576, set./dez. 2011. Seção: Estudos.

FREITAS, Luiz Carlos de; FACCENDA, Odival; DALBEN, Adilson. Capacidade explicativa de questionários de contexto: aspectos metodológicos. RBEP, v. 92, n. 231, p. 246-267, maio/ago. 2011. Seção: Estudos.

FREITAS, Marcos Antonio Braga de. O Instituto Insikiran da Universidade Federal de Roraima: trajetória das políticas para a educação superior indígena. RBEP, v. 92, n. 232, p. 599-615, set./dez. 2011. Seção: Estudos.

GALIAZZI, Maria do Carmo; ALBUQUERQUE, Fernanda Medeiros de. A formação do professor em rodas de formação. RBEP, v. 92, n. 231, p. 386398, maio/ago. 2011. Seção: Estudos.

GARCIA, Teise; BORGHI, Raquel Fontes; ADRIÃO, Theresa. As parcerias público-privadas para a oferta de vagas na educação infantil: um estudo em municípios paulistas. RBEP, v. 92, n. 231, p. 285-301, maio/ago. 2011. Seção: Estudos.

GOMES, Magno Federeci. Delimitação de atribuições educacionais: sistemas de ensino e competência constitucional. RBEP, v. 92, n. 230, p. 166-186, jan./abr. 2011. Seção: Estudos.

GONDRA, José Gonçalves; SILVA, José Cláudio Sooma. Textbooks in the History of Education: notas para pensar as narrativas de Paul Monroe, Stephen Duggan e Afranio Peixoto. RBEP, v. 92, n. 232, p. 702-722, set./ dez. 2011. Seção: Estudos.

GRISA, Gregório Durlo; DOEBBER, Michele Barcelos; . Ações afirmativas: o critério racial e a experiência da Universidade Federal do Rio Grande do Sul. RBEP, v. 92, n. 232, p. 577-598, set./dez. 2011. Seção: Estudos.

LEAL, Telma Ferraz; FERREIRA, Andrea Tereza Brito. Formação continuada e ensino da escrita: análise de estratégias formativas utilizadas no programa Pró-Letramento. RBEP, v. 92, n. 231, p. 370-385, maio/ago. 2011. Seção: Estudos.

LIMA, Anna Paula de Avelar Brito ; ARAUJO, Lucia de Fátima; SANTOS, Marcelo Câmara dos. Ruptura e efeitos do contrato didático numa aula de resolução de problemas algébricos. RBEP, v. 92, n. 232, p. 739-756, set./dez. 2011. Seção: Estudos.

LIMA, Leonardo Claver Amorim. Da universalização do ensino fundamental ao desafio de democratizar o ensino médio em 2016: o que evidenciam as estatísticas? RBEP, v. 92, n. 231, p. 268-284, maio/ago. 2011. Seção: Estudos. 
MAGINA, Sandra; PAGAN, Adriana. O ensino de Estatística na educação básica com foco na interdisciplinaridade: um estudo comparativo. RBEP, v. 92, n. 232, p. 723-738, set./dez. 2011. Seção: Estudos.

MARQUES, Waldemar; FRANCO, Fernando Silveira; SCHLINDWEIN, Marcelo Nivert. Universidade e movimentos sociais no Brasil: uma experiência de ação afirmativa. RBEP, v. 92, n. 232, p. 557-576, set./dez. 2011. Seção: Estudos.

MARTINS, Regina Maria Caruccio. Discussão em torno da noção de acompanhamento de jovens adultos na educação superior. RBEP, v. 92, n. 231, p. 417-433, maio/ago. 2011. Seção: Estudos.

MENEZES, Magali Mendes de; MOURA, Eliana P. G. de; ZUCCHETTI, Dinora Tereza. Cultura e resistência: a criação do popular e o popular como criação. RBEP, v. 92, n. 232, p. 663-677, set./dez. 2011. Seção: Estudos.

MOURA, Eliana P. G. de; ZUCCHETTI, Dinora Tereza; MENEZES, Magali Mendes de. Cultura e resistência: a criação do popular e o popular como criação. RBEP, v. 92, n. 232, p. 663-677, set./dez. 2011. Seção: Estudos.

NEITZEL, Adair Aguiar; FERRI, Cássia. Formação continuada para professores da educação básica: metodologia do currículo integrado e laboratório de vivências pedagógicas. RBEP, v. 92, n. 230, p. 52-69, jan./ abr. 2011. Seção: Estudos.

NEUBAUER, Rose (Coord.); DAVIS, Cláudia; TARTUCE, Gisela Lobo B. P.; NUNES, Marina M. R. Ensino médio no Brasil: uma análise de melhores práticas e de políticas públicas. RBEP, v. 92, n. 230, p. 11-33, jan./abr. 2011. Seção: Estudos.

NUNES, Marina M. R.; NEUBAUER, Rose (Coord.); DAVIS, Cláudia; TARTUCE, Gisela Lobo B. P. Ensino médio no Brasil: uma análise de melhores práticas e de políticas públicas. RBEP, v. 92, n. 230, p. 11-33, jan./abr. 2011. Seção: Estudos.

OSÓRIO, Mara Rejane Vieira. Professores e Educação Ambiental: implicações para o currículo. RBEP, v. 92, n. 231, p. 399-416, maio/ago. 2011. Seção: Estudos.

PAGAN, Adriana; MAGINA, Sandra. O ensino de Estatística na educação básica com foco na interdisciplinaridade: um estudo comparativo. RBEP, v. 92, n. 232, p. 723-738, set./dez. 2011. Seção: Estudos.

PEREIRA, Júlio Emílio Diniz. O ovo ou a galinha: a crise da profissão docente e a aparente falta de perspectiva para a educação brasileira. RBEP, v. 92, n. 230, p. 34-51, jan./abr. 2011. Seção: Estudos. 
PEREIRA, Marcos Villela; FARE, Mónica de La. A formação de professores para Educação de Jovens e Adultos (EJA): as pesquisas na Argentina e no Brasil. RBEP, v. 92, n. 230, p. 70-82, jan./abr. 2011. Seção: Estudos.

PEREIRA, Sueli Menezes; ZIENTARSKI, Clarice. Políticas de ações afirmativas e pobreza no Brasil. RBEP, v. 92, n. 232, p. 493-515, set./dez. 2011. Seção: Estudos.

PORTES, Écio Antônio; SOUSA, Letícia Pereira. As propostas de políticas/ ações afirmativas das universidades públicas e as políticas/ações de permanência nos ordenamentos legais. RBEP, v. 92, n. 232, p. 516-541, set./dez. 2011. Seção: Estudos.

ROIZ, Diogo da Silva. Dos mitos de fundação às práticas políticas: os projetos de usos do passado em questão. RBEP, v. 92, n. 232, p. 765-769, set./dez. 2011. Seção: Resenhas.

ROSISTOLATO, Rodrigo Pereira da Rocha. Juventudes populares em um pré-vestibular: a construção coletiva de expectativas e campos de possibilidades educacionais. RBEP, v. 92, n. 232, p. 616-638, set./dez. 2011. Seção: Estudos.

SANT'ANA, Ruth Bernardes de; BUENO, Fabrício Aparecido. A experiência geracional na fala de alunos de escola pública: a questão da autoridade docente. RBEP, v. 92, n. 231, p. 316-340, maio/ago. 2011. Seção: Estudos.

SANTOS, Marcelo Câmara dos ; ARAUJO, Lucia de Fátima; LIMA, Anna Paula de Avelar Brito. Ruptura e efeitos do contrato didático numa aula de resolução de problemas algébricos. RBEP, v. 92, n. 232, p. 739-756, set./dez. 2011. Seção: Estudos.

SANTOS, Valéria de Oliveira. A história da educação escrita por meio de práticas e ações pedagógicas. RBEP, v. 92, n. 230, p. 201-203, jan./abr. 2011. Seção: Resenhas.

SCHLINDWEIN, Marcelo Nivert; MARQUES, Waldemar; FRANCO, Fernando Silveira. Universidade e movimentos sociais no Brasil: uma experiência de ação afirmativa. RBEP, v. 92, n. 232, p. 557-576, set./dez. 2011. Seção: Estudos.

SILVA, José Cláudio Sooma; GONDRA, José Gonçalves. Textbooks in the History of Education: notas para pensar as narrativas de Paul Monroe, Stephen Duggan e Afranio Peixoto. RBEP, v. 92, n. 232, p. 702-722, set./ dez. 2011. Seção: Estudos.

SILVA, Maria Helena G. Frem Dias da. Reinterpretando conceitos cristalizados com os professores: um degrau prévio para enfrentar os 
dilemas profissionais docentes. RBEP, v. 92, n. 231, p. 341-369, maio/ ago. 2011. Seção: Estudos.

SILVA, Sérgio Pereira da. Pedagogia do Ressentimento: o otimismo nas concepções e nas práticas de ensino. RBEP, v. 92, n. 230, p. 107-125, jan./ abr. 2011. Seção: Estudos.

SIQUEIRA, Flávia Zanni. Psicanálise aplicada ao estudo do cotidiano escolar. RBEP, v. 92, n. 230, p. 187-199, jan./abr. 2011. Seção: Estudos.

SIQUEIRA, Idméa Semeghini. Recursos educacionais apropriados para recuperação lúdica do processo de letramento emergente. RBEP, v. 92, n. 230, p. 148-165, jan./abr. 2011. Seção: Estudos.

SOUSA, Letícia Pereira; PORTES, Écio Antônio. As propostas de políticas/ ações afirmativas das universidades públicas e as políticas/ações de permanência nos ordenamentos legais. RBEP, v. 92, n. 232, p. 516-541, set./dez. 2011. Seção: Estudos.

TARTUCE, Gisela Lobo B. P.; NEUBAUER, Rose (Coord.); DAVIS, Cláudia; NUNES, Marina M. R. Ensino médio no Brasil: uma análise de melhores práticas e de políticas públicas. RBEP, v. 92, n. 230, p. 11-33, jan./abr. 2011. Seção: Estudos.

VAZ, Alexandre Fernandez; AZEVEDO, Fernanda Vicente de; BOMBASSARO, Ticiane. Escolarização do corpo e controle de si na revista Estudos Educacionais. RBEP, v. 92, n. 231, p. 302-315, maio/ago. 2011. Seção: Estudos.

VELLOSO, Jacques; CARDOSO, Claudete Batista. Um quinquênio de cotas: as chances de ingresso de negros na Universidade de Brasília. RBEP, v. 92, n. 231, p. 221-245, maio/ago. 2011. Seção: Estudos.

VOLPATO, Gildo. A universidade na sua constituição: criação, reformas e implicações político-epistemológicas. RBEP, v. 92, n. 232, p. 678-701, set./dez. 2011. Seção: Estudos.

ZIENTARSKI, Clarice; PEREIRA, Sueli Menezes. Políticas de ações afirmativas e pobreza no Brasil. RBEP, v. 92, n. 232, p. 493-515, set./dez. 2011. Seção: Estudos.

ZUCCHETTI, Dinora Tereza; MOURA, Eliana P. G. de; MENEZES, Magali Mendes de. Cultura e resistência: a criação do popular e o popular como criação. RBEP, v. 92, n. 232, p. 663-677, set./dez. 2011. Seção: Estudos. 



\section{Índice de títulos RBEP}

Ações afirmativas: o critério racial e a experiência da Universidade Federal do Rio Grande do Sul.

DOEBBER, Michele Barcelos; GRISA, Gregório Durlo. Ações afirmativas: o critério racial e a experiência da Universidade Federal do Rio Grande do Sul. RBEP, v. 92, n. 232, p. 577-598, set./dez. 2011. Seção: Estudos.

Alfabetização e letramento no $1^{\circ}$ ciclo: o que as crianças aprendem sobre a escrita a cada ano?

CRUZ, Magna Silva; ALBUQUERQUE, Eliana Borges. Alfabetização e letramento no $1^{\circ}$ ciclo: o que as crianças aprendem sobre a escrita a cada ano? RBEP, v.92, n. 230, p. 126-147, jan./abr. 2011. Seção: Estudos.

As propostas de políticas/ações afirmativas das universidades públicas e as políticas/ações de permanência nos ordenamentos legais.

SOUSA, Letícia Pereira; PORTES, Écio Antônio. As propostas de políticas/ ações afirmativas das universidades públicas e as políticas/ações de permanência nos ordenamentos legais. RBEP, v. 92, n. 232, p. 516-541, set./dez. 2011. Seção: Estudos.

Autobiografias e formação: aproximações problemáticas no Movimento Pesquisa/Formação.

CESTARI, Luiz Artur Santos. Autobiografias e formação: aproximações problemáticas no Movimento Pesquisa/Formação. RBEP, v. 92, n. 230, p. 83-106, jan./abr. 2011. Seção: Estudos. 
Capacidade explicativa de questionários de contexto: aspectos metodológicos.

FACCENDA, Odival; DALBEN, Adilson; FREITAS, Luiz Carlos de. Capacidade explicativa de questionários de contexto: aspectos metodológicos. RBEP, v. 92, n. 231, p. 246-267, maio/ago. 2011. Seção: Estudos.

Cultura e resistência: a criação do popular e o popular como criação. MOURA, Eliana P. G. de; ZUCCHETTI, Dinora Tereza; MENEZES, Magali Mendes de. Cultura e resistência: a criação do popular e o popular como criação. RBEP, v. 92, n. 232, p. 663-677, set./dez. 2011. Seção: Estudos.

Da universalização do ensino fundamental ao desafio de democratizar o ensino médio em 2016: o que evidenciam as estatísticas?

LIMA, Leonardo Claver Amorim. Da universalização do ensino fundamental ao desafio de democratizar o ensino médio em 2016: o que evidenciam as estatísticas? RBEP, v. 92, n. 231, p. 268-284, maio/ago. 2011. Seção: Estudos.

Delimitação de atribuições educacionais: sistemas de ensino e competência constitucional.

GOMES, Magno Federeci. Delimitação de atribuições educacionais: sistemas de ensino e competência constitucional. RBEP, v. 92, n. 230, p. 166-186, jan./abr. 2011. Seção: Estudos.

Discussão em torno da noção de acompanhamento de jovens adultos na educação superior.

MARTiNS, Regina Maria Caruccio. Discussão em torno da noção de acompanhamento de jovens adultos na educação superior. RBEP, v. 92, n. 231, p. 417-433, maio/ago. 2011. Seção: Estudos.

Dos mitos de fundação às práticas políticas: os projetos de usos do passado em questão.

ROIZ, Diogo da Silva. Dos mitos de fundação às práticas políticas: os projetos de usos do passado em questão. RBEP, v. 92, n. 232, p. 765-769, set./dez. 2011. Seção: Resenhas.

Educação e imaginário intercultural: recomposição do papel da sociedade civil.

BARBOSA, Manuel Gonçalves. Educação e imaginário intercultural: recomposição do papel da sociedade civil. RBEP, v. 92, n. 232, p. 477-492, set./dez. 2011. Seção: Estudos.

ensino de Estatística na educação básica com foco na interdisciplinaridade: um estudo comparativo. 0 .

PAGAN, Adriana; MAGINA, Sandra. O ensino de Estatística na educação básica com foco na interdisciplinaridade: um estudo comparativo. RBEP, v. 92, n. 232, p. 723-738, set./dez. 2011. Seção: Estudos. 
Ensino médio no Brasil: uma análise de melhores práticas e de políticas públicas.

NEUBAUER, Rose (Coord.); DAVIS, Cláudia; TARTUCE, Gisela Lobo B. P.; NUNES, Marina M. R. Ensino médio no Brasil: uma análise de melhores práticas e de políticas públicas. RBEP, v. 92, n. 230, p. 11-33, jan./abr. 2011. Seção: Estudos.

Escolarização do corpo e controle de si na revista Estudos Educacionais. AZEVEDO, Fernanda Vicente de; BOMBASSARO, Ticiane; VAZ, Alexandre Fernandez. Escolarização do corpo e controle de si na revista Estudos Educacionais. RBEP, v. 92, n. 231, p. 302-315, maio/ago. 2011. Seção: Estudos.

experiência geracional na fala de alunos de escola pública: a questão da autoridade docente. A.

BUENO, Fabrício Aparecido; SANT'ANA, Ruth Bernardes de. A experiência geracional na fala de alunos de escola pública: a questão da autoridade docente. RBEP, v. 92, n. 231, p. 316-340, maio/ago. 2011. Seção: Estudos.

Estudantes de camadas populares e o ingresso na vida universitária. ÁVILA, Rebeca Contrera. Estudantes de camadas populares e o ingresso na vida universitária. RBEP, v. 92, n. 232, p. 757-764, set./dez. 2011. Seção: Resenhas.

Formação continuada e ensino da escrita: análise de estratégias formativas utilizadas no programa Pró-Letramento.

LEAL, Telma Ferraz; FERREIRA, Andrea Tereza Brito. Formação continuada e ensino da escrita: análise de estratégias formativas utilizadas no programa Pró-Letramento. RBEP, v. 92, n. 231, p. 370-385, maio/ago. 2011. Seção: Estudos.

Formação continuada para professores da educação básica: metodologia do currículo integrado e laboratório de vivências pedagógicas.

NEITZEL, Adair Aguiar; FERRI, Cássia. Formação continuada para professores da educação básica: metodologia do currículo integrado e laboratório de vivências pedagógicas. RBEP, v. 92, n. 230, p. 52-69, jan./ abr. 2011. Seção: Estudos.

formação de professores para Educação de Jovens e Adultos(EJA): as pesquisas na Argentina e no Brasil. A.

PEREIRA, Marcos Villela; FARE, Mónica de La. A formação de professores para Educação de Jovens e Adultos (EJA): as pesquisas na Argentina e no Brasil. RBEP, v. 92, n. 230, p. 70-82, jan./abr. 2011. Seção: Estudos.

formação do professor em rodas de formação. A.

ALBUQUERQUE, Fernanda Medeiros de; GALIAZZI, Maria do Carmo. A formação do professor em rodas de formação. RBEP, v. 92, n. 231, p. 386398, maio/ago. 2011. Seção: Estudos. 
Gestão da educação escolar indígena diferenciada: contradições, limites e possibilidades.

BRUNO, Lúcia. Gestão da educação escolar indígena diferenciada: contradições, limites e possibilidades. RBEP, v. 92, n. 232, p. 639-662, set./dez. 2011. Seção: Estudos.

história da educação escrita por meio de práticas e ações pedagógicas. A. SANTOS, Valéria de Oliveira. A história da educação escrita por meio de práticas e ações pedagógicas. RBEP, v. 92, n. 230, p. 201-203, jan./abr. 2011. Seção: Resenhas.

Instituto Insikiran da Universidade Federal de Roraima: trajetória das políticas para a educação superior indígena. $\mathbf{O}$.

FREITAS, Marcos Antonio Braga de. O Instituto Insikiran da Universidade Federal de Roraima: trajetória das políticas para a educação superior indígena. RBEP, v. 92, n. 232, p. 599-615, set./dez. 2011. Seção: Estudos.

Juventudes populares em um pré-vestibular: a construção coletiva de expectativas e campos de possibilidades educacionais.

ROSISTOLATO, Rodrigo Pereira da Rocha. Juventudes populares em um pré-vestibular: a construção coletiva de expectativas e campos de possibilidades educacionais. RBEP, v. 92, n. 232, p. 616-638, set./dez. 2011. Seção: Estudos.

ovo ou a galinha: a crise da profissão docente e a aparente falta de perspectiva para a educação brasileira. 0 .

PEREIRA, Júlio Emílio Diniz. O ovo ou a galinha: a crise da profissão docente e a aparente falta de perspectiva para a educação brasileira. RBEP, v. 92, n. 230, p. 34-51, jan./abr.2011. Seção: Estudos.

parcerias público-privadas para a oferta de vagas na educação infantil: um estudo em municípios paulistas. As.

BORGHI, Raquel Fontes; ADRIÃO, Theresa; GARCIA, Teise. As parcerias público-privadas para a oferta de vagas na educação infantil: um estudo em municípios paulistas. RBEP, v. 92, n. 231, p. 285-301, maio/ago. 2011. Seção: Estudos.

Pedagogia do Ressentimento: o otimismo nas concepções e nas práticas de ensino.

SILVA, Sérgio Pereira da. Pedagogia do Ressentimento: o otimismo nas concepções e nas práticas de ensino. RBEP, v. 92, n. 230, p. 107-125, jan./ abr. 2011. Seção: Estudos.

Políticas afirmativas para a inclusão do surdo no ensino superior: algumas reflexões sobre o acesso, a permanência e a cultura universitária.

BRUNO, Marilda Moraes Garcia. Políticas afirmativas para a inclusão do surdo no ensino superior: algumas reflexões sobre o acesso, a permanência 
e a cultura universitária. RBEP, v. 92, n. 232, p. 542-556, set./dez. 2011. Seção: Estudos.

Políticas de ações afirmativas e pobreza no Brasil.

PEREIRA, Sueli Menezes; ZIENTARSKI, Clarice. Políticas de ações afirmativas e pobreza no Brasil. RBEP, v. 92, n. 232, p. 493-515, set./dez. 2011. Seção: Estudos.

Por um olhar democrático às ações afirmativas.

AGOSTINHO, Luis Otávio Vincenzi; BREGA FILHO, Vladimir. Por um olhar democrático às ações afirmativas. RBEP, v. 92, n. 232, p. 455-476, set./ dez. 2011. Seção: Estudos.

Professores e Educação Ambiental: implicações para o currículo. OSÓRIO, Mara Rejane Vieira. Professores e Educação Ambiental: implicações para o currículo. RBEP, v. 92, n. 231, p. 399-416, maio/ago. 2011. Seção: Estudos.

Psicanálise aplicada ao estudo do cotidiano escolar.

SIQUEIRA, Flávia Zanni. Psicanálise aplicada ao estudo do cotidiano escolar. RBEP, v. 92, n. 230, p. 187-199, jan./abr. 2011. Seção: Estudos.

quinquênio de cotas: as chances de ingresso de negros na Universidade de Brasília. Um.

VELLOSO, Jacques; CARDOSO, Claudete Batista. Um quinquênio de cotas: as chances de ingresso de negros na Universidade de Brasília. RBEP, v. 92, n. 231, p. 221-245, maio/ago. 2011. Seção: Estudos.

Recursos educacionais apropriados para recuperação lúdica do processo de letramento emergente.

SIQUEIRA, Idméa Semeghini. Recursos educacionais apropriados para recuperação lúdica do processo de letramento emergente. RBEP, v. 92, n. 230, p. 148-165, jan./abr. 2011. Seção: Estudos.

Reinterpretando conceitos cristalizados com os professores: um degrau prévio para enfrentar os dilemas profissionais docentes.

SILVA, Maria Helena G. Frem Dias da. Reinterpretando conceitos cristalizados com os professores: um degrau prévio para enfrentar os dilemas profissionais docentes. RBEP, v. 92, n. 231, p. 341-369, maio/ ago. 2011. Seção: Estudos.

Ruptura e efeitos do contrato didático numa aula de resolução de problemas algébricos.

ARAUJO, Lucia de Fátima; LIMA, Anna Paula de Avelar Brito; SANTOS, Marcelo Câmara dos. Ruptura e efeitos do contrato didático numa aula de resolução de problemas algébricos. RBEP, v. 92, n. 232, p. 739-756, set./dez. 2011. Seção: Estudos. 
Textbooks in the History of Education: notas para pensar as narrativas de Paul Monroe, Stephen Duggan e Afranio Peixoto.

SILVA, José Cláudio Sooma; GONDRA, José Gonçalves. Textbooks in the History of Education: notas para pensar as narrativas de Paul Monroe, Stephen Duggan e Afranio Peixoto. RBEP, v. 92, n. 232, p. 702-722, set./ dez. 2011. Seção: Estudos.

Universidade e movimentos sociais no Brasil: uma experiência de ação afirmativa.

MARQUES, Waldemar; FRANCO, Fernando Silveira; SCHLINDWEIN, Marcelo Nivert. Universidade e movimentos sociais no Brasil: uma experiência de ação afirmativa. RBEP, v. 92, n. 232, p. 557-576, set./dez. 2011. Seção: Estudos.

universidade na sua constituição: criação, reformas e implicações político-epistemológicas. A.

VOLPATO, Gildo. A universidade na sua constituição: criação, reformas e implicações político-epistemológicas. RBEP, v. 92, n. 232, p. 678-701, set./dez. 2011. Seção: Estudos. 